\title{
Isolation and characterization of novel plant growth-promoting rhizobacteria (PGPR) isolates from tomato (Solanum lycopersicum L.) rhizospherical soil: A novel IAA producing bacteria
}

\author{
Narjes H. Dashti ${ }^{*}$, Nedaa Y. Ali Al-Sarraf, Vineetha M. Cherian, Magdy S. Montasser \\ Dept. of Biological Sciences, College of Science, Research Administration, Research Grant \# \\ SL07/12, Kuwait University, P.O. Box 5969, Safat 13060, Kuwait \\ *Corresponding author: narjes.dashti@ku.edu.kw
}

\begin{abstract}
Indole acetic acid (IAA) production is one of the distinctive traits of plant growth-promoting rhizobacteria (PGPR). Ten different rhizobacterial strains were isolated from the roots of tomato crops (Solanum lycopersicum L.), grown in Kuwait, and then screened for their plant growth-promoting abilities, with emphasis on IAA production. The isolated strains were identified by $16 \mathrm{~S}$ partial r-RNA sequencing and further characterized by conventional biochemical tests. Based on the nucleotide sequence analysis and homology of the isolates, a phylogenetic tree was constructed. The plant growth-promoting abilities of the strains were determined by testing for ammonium production, hydrogen cyanide and acid production, growth in nitrogen-free media, phosphate solubilization, and IAA production. The potential IAA PGPRs were re-applied onto the rhizosphere of green-house grown tomato plants to determine their effects on tomato growth. The results have indicated that all isolated strains were able to produce indole acetic acid even without the presence of a tryptophan precursor.
\end{abstract}

Keywords: IAA; PGPR; rhizosphere; tomato; tryptophan.

\section{Introduction}

Plant growth-promoting rhizobacteria (PGPR) are beneficial soil microorganisms that colonize the plant roots and aid in the growth and protection of their host plants (Reetha et al., 2014; Sharma \& Rai, 2015). The three major pathways of beneficial interaction between the PGPRs and their host plants include Phytostimulation, biofertilization, and biocontrol (Sahran \& Nehra, 2011; Mohite, 2013). Phytostimulation promotes plant growth by producing certain phytohormones that play a direct role in altering the host physiology. Biofertilization enhances the plants' nutrition absorption capability by increasing the availability of essential nutrients such as nitrogen, phosphorous, and iron. Biocontrol is often achieved by producing certain antagonistic metabolites that target certain plant pathogens and induce systemic resistance (Abbamondi et al., 2016).

One of the most physiologically active auxins found naturally occurring in young leaves, stems, and seeds of plants is indole acetic acid (IAA). Many beneficial plant growth-promoting bacteria are involved in the production of IAA by transamination and decarboxylation reaction of the amino acid L-tryptophan (Mohite, 2013). IAA helps in the production of longer roots with an increased number of root hairs and root laterals which are involved in nutrient uptake (Gravel et al., 2007; Mohite, 2013). 
There have been many reports of IAA producing PGPR species found in many plants' rhizosphere, especially tomato (Gravel et al., 2007; Idris et al., 2007; Mohite, 2013). Tomato is one of the chief crop plants in Kuwait. Many studies have categorized the majority of the microflora isolated from the tomato rhizosphere as belonging to three pre-dominant genera: Bacillus, Pseudomonas, and Burkholderia (Bashan \& De-Bashan, 2002; CaballeroMellado et al., 2007; Kumar et al., 2012; Laslo et al., 2012).

Many of these IAA producing have proven themselves to be excellent PGPRs promoting the growth, development, and protection of many plants (Idris et al., 2007; Mohite, 2013; Reetha et al., 2014). However, no research has been conducted to study the IAA producing PGPR species in the rhizosphere of tomatoes in Kuwait. This work aimed at a) isolating novel IAA producing PGPRs from the rhizosphere of tomato plants in Kuwait; b) testing the effects of IAA producing bacteria on the growth and development of greenhousegrown tomato plants in the presence and absence of the IAA precursor tryptophan.

\section{Materials \& Methods}

\subsection{Bacterial sample collections soil} samples

Soil samples were collected from agricultural farms in Abdally $30^{\circ} 01^{\prime} 39.6^{\prime \prime} \mathrm{N}$ $47^{\circ} 44^{\prime} 51.4^{\prime \prime} \mathrm{E}$ and Wafra $28.5930^{\circ} \mathrm{N}$, $48.1049^{\circ} \mathrm{E}$ in Kuwait. The tomato plants (al-Jawhara) were grown in greenhouses to protect the plants from the arid desert climatic conditions outside. The natural soil of Abdally is sandy and poor in nutrients, while the soil in Wafra is non-gypsiferous, calcareus, non-saline. Both soil types have very low organic contents. Hence, to grow the tomato plants, both soil types were modified by manually incorporating organic fertilizers. (Shahid et al., 2004, AlShattie \& Meneie, 2015). At the fruiting stage, the plants were uprooted from the soil without disturbing the soil surrounding the root. The intact root systems collected were immediately transported to the lab, and analysis was started as follows within 24 hours. Ten grams of soil sample were suspended in $90 \mathrm{ml}$ sterile distilled water and were shaken in an incubator shaker at $30^{\circ} \mathrm{C}$ for $10 \mathrm{~min}$. Then, $100 \mu \mathrm{l}$ of the suspension after serial dilution were spread on the nutrient agar medium plates. Plates were incubated at 28 to $30^{\circ} \mathrm{C}$ for 24 to 40 hrs. The various colonies obtained were isolated, purified, and stored at $-80^{\circ} \mathrm{C}$ Microbank cryovials in the Kuwait University Microbiology lab.

2.2 Biochemical and molecular characterization of the isolated strains

Biochemical tests were conducted using Biomerieux API strips (20 E). Genotypic characterization was carried out by partial 16S r-RNA sequencing as described by Dashti et al., 2009. DNA was extracted using Prepman ultra sample preparation reagent (Life Technologies). PCR analysis using Pure Taq ready-to-go PCR beads (GE Healthcare) and universal primers (forward: GM5F; reverse: 907R) was conducted on a Veriti Thermal Cycler (Applied Biosystems). The sequences obtained were aligned and submitted to the Basic Local Alignment Search Tool (BLAST) to check for the homology of the isolated strains with the existing database. The phylogenetic tree was constructed using the TREEVIEW and the PAUP 4.0 tools (Pavlopoulos et al., 2010).

2.3 Determining the antimicrobial susceptibility test of the strains

The antimicrobial susceptibility test was determined by the disk diffusion method as described by Wani \& Irene, 2014. Susceptibility was determined by measuring the zone of inhibition diameter around the disks. All the isolated strains were tested against 6 different antimicrobial agents. 
2.4 Screening for PGPR activity of the isolated strains

\subsubsection{Ammonia production}

Bacterial cultures were tested in peptone water as per the protocol described by Laslo et al., 2012. $24 \mathrm{hr}$ old cultures were transferred to $10 \mathrm{ml}$ peptone water. After incubation for $48-72 \mathrm{hr}$ freshly grown cultures were inoculated in $10 \mathrm{ml}$ peptone water and incubated for 48-72 hrs at $30 \pm 2$ ${ }^{\circ} \mathrm{C}$, the cultures were treated with Nessler's reagent $(0.5 \mathrm{ml})$. The development of brown indicated positive ammonia production to yellow color.

\subsubsection{Hydrogen cyanide $(\mathrm{HCN})$ production}

Bacterial isolates were streaked on nutrient agar amended with $4.4 \mathrm{~g}$ glycine/L, then overlaid with a filter paper soaked with $2 \%$ sodium carbonate in $0.5 \%$ picric acid. Plates were incubated for 4 days. The development of an orange-red color indicated the $\mathrm{HCN}$ production (Wani \& Irene, 2014).

\subsubsection{Acid production}

Bacterial isolates were grown on yeast mannitol agar supplemented with $0.08 \%$ bromothimol blue (BTB). The presence of yellow halos on the media was due to acid production (Koskey et al., 2018).

\subsubsection{Nitrogen fixing capability}

Bacterial isolates were screened for nitrogen-fixing capability following the procedure described by Sharma \& Rai, 2015. The production of a blue-green color after 1 week of incubation confirms nitrogen-fixing capability.

\subsubsection{Phosphate solubilization}

Pikovyskaya's agar determined the tricalcium phosphate solubilization ability of the bacterial strains. The positive test was indicated by the clear zone of inhibition around the colony after 48-72 hrs. of incubation (Kumar et al., 2012; Laslo et al., 2012).

\subsubsection{Indole acetic acid production}

IAA production capability of the isolated strains was measured using the Salkowski method (Mohite, 2013). The positive reaction was indicated when the color changes from yellow to cherry red (Mohite, 2013).

2.5 Quantitative estimation of IAA production by different strains using spectrophotometrical analysis

The isolates were grown in Luria Bertani Broth (LB) (Himedia, India). The broth was centrifuged after incubation. $1 \mathrm{ml}$ of the supernatant was mixed with $2 \mathrm{ml}$ of Salkowski's reagent and kept in the dark. The optical density (OD) was recorded at $530 \mathrm{~nm}$ after $30 \mathrm{~min}$. In order to see if the addition of tryptophan improves the IAA production, the bacterial cultures were grown in three different tryptophan concentration, and the amount of IAA produced were measured by spectrophotometric analysis.

2.6 Effect of IAA producing bacteria on the growth of tomato plants

Seeds of tomato were surface sterilized in sodium hypochlorite $(2 \%$ solution containing $4 \mathrm{ml} \mathrm{L}^{-1}$ Tween 20) then rinsed with distilled water (Dashti et al., 2014). The seeds were planted into pots containing sterile soil. The sterility of the soil was carried at 121 for 20 minutes for 3 successive days to ensure the removal of spores (Dashti et al., 2014). The temperature of the greenhouse was maintained between 25-30. The relative humidity was maintained between $65 \%$ to $90 \%$ by proper watering, spacing, water drainage methods, and ventilations. The light-dark cycle was ensured by ensuring the proper placement of plants such that they had sufficient sunlight during the day and dark at night (16-18hrs of sunlight and $6-8 \mathrm{hrs}$ of the dark period). The growth conditions specified above were validated and established in-house based on the tomatoes' optimal growth conditions and 
the greenhouse construction specifications. Following germination, the seedlings were thinned to one plant per pot. Treatments were arranged in a randomized complete block design. The entire study was confirmed with three replications of consecutive sets of experiments. The bacterial isolates (approx. $10^{6}$ cells $/ \mathrm{ml}$ ) were inoculated directly into the rhizosphere. Plants were harvested at the end of 30 days.

Chlorophyll estimation: Tomato leaves were grinded in $80 \%$ acetone, centrifuged at $10,000 \mathrm{rpm}$ for 5 minutes. The supernatants were then combined together, made up to $50 \mathrm{ml}$ with acetone, and the absorbance was measured at 645 and $663 \mathrm{~nm}$. (Jianfeng et al., 2015).

Protein estimation: The protein content of the tomato leaves was estimated by the Bradford method using Coomassie brilliant blue G-250 as the color indicator. Absorbance was read at $595 \mathrm{~nm}$ (Dashti et al., 2014).

Proline estimation: $1 \mathrm{ml}$ of the sample extracted in 3\% aqueous sulphosalicyclic acid $(0.01 \mathrm{~g} / 0.5 \mathrm{ml})$ was allowed to react with equal amounts of glacial acetic acid and acid ninhydrin for about an hour in the water bath at $100^{\circ} \mathrm{C}$. The optical density of the samples was measured at $520 \mathrm{~nm}$ using Toluene as the blank (Abraham et al., 2010).

\subsection{Statistical analysis}

Graphs were constructed using the GraphPad prism (v. 6.0). Analysis of variance (ANOVA) at $\mathrm{P}=0.05$ was performed on the data obtained using the SPSS (Statistical Package for Social sciences) -PASW statistics 18 software, and the means were separated with Duncan's Multiple Range Test (DMRT) using PASW statics 18 and the Michigan University Statistical Package (MSTATC) software.

\section{Results}

3.1 Isolation and characterization of different strains isolated from tomato rhizosphere

Three strains were isolated from the samples obtained from Abdally farms labelled A1-A3, and 7 strains were isolated from Wafra labelled W1-W7. Gram staining of the isolates indicated that all the strains isolated from Abdally were gram-positive rods. Four out of the 7 strains isolated from Wafra were gram-negative rods, while three were grampositive rods. Biochemical screening of the isolates, both by conventional methods (Kumar et al., 2012) and the API strips, are presented in Tables 1 and 2. The results showed that A1, A2, A3, W4, and W7 all belong to Bacillus species while W1, W2, W3, and W6 belong to Pseudomonas species. All the isolated Bacilli were tested positive for acetoin production (Vogues Proskuer test) as well as catalase test. All the isolated Pseudomonas strains tested positive for the Arginine dihydrolase (ADH) enzyme. All the isolated strains were negative for lysine decarboxylase, ornithine de-carboxylase, and hydrogen sulfide production. Most of the strains except for W1, W5, and W3 were able to ferment at least one sugar type (Table 2). Strains A1 and A3 have very similar biochemical properties and could only be differentiated with their ability to ferment inositol. A1 tested negative for inositol and starch hydrolysis, while A3 tested positive (Tables 1 and 2). The 16S rRNA sequence analyses of the bacterial samples confirm the findings obtained from the Biochemical tests. Identification of isolated bacterial samples based on 16S rRNA sequence analysis using Basic Local Alignment Search Tool (BLAST) are presented in Table 3 and Figure $1 \mathrm{a} \& \mathrm{~b}$. The evolutionary relationship between the different samples is shown in Figure 2. All the boot-strap values higher than 50 are indicated at the nodes of the tree. These values indicate the most likely position of the different species on the tree in relation to the rest of the isolates. The values confirm the BLAST results obtained. 
Table 1. Biochemical screening of bacterial isolates from Abdally and Wafra farms.

\begin{tabular}{|lllllllllll||}
\hline Biochemical tests & \multicolumn{8}{c|}{ Bacterial isolates as designated in the lab } \\
& $\mathbf{A 1}$ & $\mathbf{A 2}$ & $\mathbf{A 3}$ & $\mathbf{W 1}$ & $\mathbf{W} 2$ & $\mathbf{W 3}$ & $\mathbf{W} 4$ & $\mathbf{W 5}$ & $\mathbf{W 6}$ & $\mathbf{W 7}$ \\
Catalase & + & + & + & - & - & + & + & + & + & + \\
$\beta$-galactosidase & + & + & + & - & - & + & - & - & - & - \\
Arginine- & - & - & - & + & + & + & + & + & + & - \\
Dihydrolase & & & & & & & & & & \\
Lysine & - & - & - & - & - & - & - & - & - & - \\
& & & & & & & & & & \\
de-carboxylase & & & & & & & & & & \\
Ornithine & - & - & - & - & - & - & - & - & - & - \\
& & & & & & & & & & \\
de-carboxylase & & & & & & & & & & \\
Citrate utilization & + & + & + & - & + & + & + & + & + & + \\
H2S production & - & - & - & - & - & - & - & - & - & - \\
Urea hydrolysis & + & + & + & + & + & + & + & + & + & + \\
Acetoine & + & + & + & - & - & - & + & + & - & + \\
Indole production & - & - & - & - & - & - & + & + & + & - \\
Gelatinase & + & + & + & + & - & + & + & + & + & + \\
Spore formation & + & + & + & - & - & - & + & + & - & + \\
Starch hydrolysis & - & + & + & - & - & - & + & - & - & + \\
Nitrate reduction & - & + & - & - & - & - & + & + & - & + \\
\hline
\end{tabular}

A1-A3: Bacterial strains isolated from Abdally; W1-W7: Bacterial strains isolated from Wafra. '+' sign indicates that the isolates show a positive reaction for the tested parameters, and the '-'sign indicates that the isolates show a negative reaction to the tested parameters.

Table 2. Carbohydrate fermentation ability of the isolated bacterial strains.

\begin{tabular}{|llllllllllll||}
\hline Type of & & \multicolumn{8}{c||}{ Bacterial isolates as designated in the lab } \\
& $\mathbf{A 1}$ & $\mathbf{A} 2$ & $\mathbf{A 3}$ & $\mathbf{W 1}$ & $\mathbf{W 2}$ & $\mathbf{W 3}$ & $\mathbf{W 4}$ & $\mathbf{W 5}$ & W6 & W7 \\
Carbohydrate & & & & & & & & & & \\
Glucose & + & + & + & - & - & - & + & - & + & + \\
Mannitol & + & + & + & - & - & - & - & - & + & + \\
Inositol & - & - & + & - & + & - & - & - & - & - \\
Sorbitol & - & + & - & - & - & - & - & - & - & + \\
& & & & & & & & & & \\
Rhamnose & - & - & - & - & - & - & - & - & - & - \\
Sucrose & + & + & + & - & + & - & - & - & - & + \\
Melibiose & - & - & - & - & - & - & - & - & - & - \\
Amygdalin & + & - & + & - & - & - & - & - & - & - \\
Arabinose & + & - & + & - & - & - & - & - & + & - \\
\hline
\end{tabular}

A1-A3: Bacterial samples isolated from Abdally; W1-W7: Bacterial samples isolated from Wafra. '+' sign indicates that the isolates show a positive reaction for the tested parameters, and the "-'sign indicates that the isolates show a negative reaction to the tested parameters. 


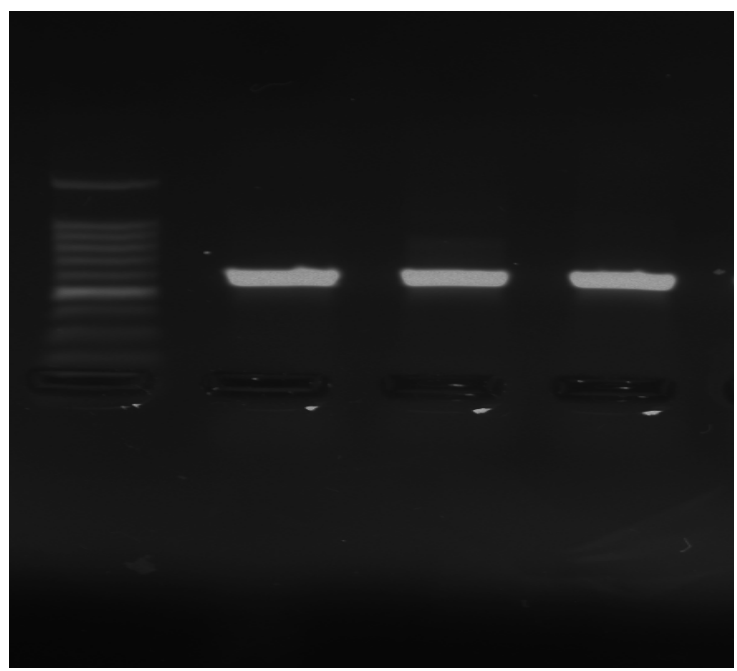

(A)

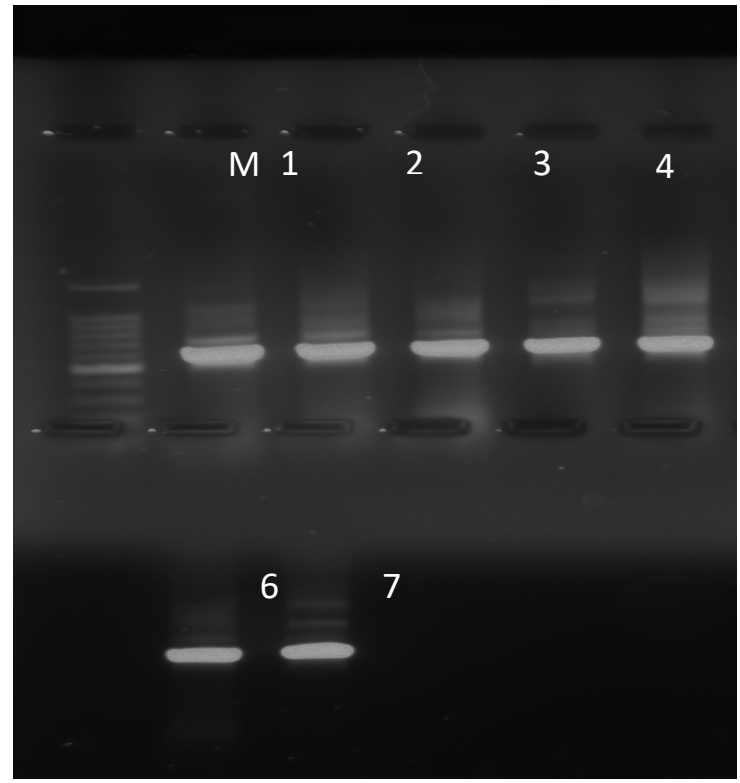

(B)

Fig. 1. A) DNA bands after PCR amplification observed on $1 \%$ agarose gel stained with ethidium bromide for strains isolated from Abdally. M: 1kb DNA ladder; Lane1: strain A1; Lane 2: strain A2; Lane 3: strain A3.

B) DNA bands after PCR amplification observed on 1\% agarose gel stained with ethidium bromide for samples isolated from Wafra. M: 1kb DNA ladder; Lane1: strain W1; Lane 2: strain W2; Lane 3: strain W3; Lane 4: strain W4; Lane

6: strain W6; Lane 7: strain W7. 
Table 3. Identification of isolated bacterial samples based on 16S rRNA sequence analysis using basic local alignment search tool (BLAST)

\begin{tabular}{|c|c|c|c|c|c|}
\hline $\begin{array}{l}\text { Sample } \\
\text { ID }\end{array}$ & Nearest match & Subdivision & $\begin{array}{c}\begin{array}{c}\text { Similar } \\
\text { ity }\end{array} \\
(\%)\end{array}$ & $\begin{array}{l}\text { Bases } \\
\text { compar } \\
\text { ed }\end{array}$ & $\begin{array}{l}\text { Accession } \\
\text { number }\end{array}$ \\
\hline A1 & Bacillus pumilus & Firmicutes & 99 & 438 & HQ433246 \\
\hline $\mathrm{A} 2$ & Bacillus subtilis & Firmicutes & 100 & 480 & KM462851 \\
\hline A3 & Bacillus safensis & Firmicutes & 97 & 446 & LN650578 \\
\hline W1 & $\begin{array}{l}\text { Pseudomonas } \\
\text { plecoglosscida }\end{array}$ & Proteobacteria & 99 & 416 & FJ605372 \\
\hline W2 & $\begin{array}{l}\text { Pseudomonas } \\
\text { brassicacearum }\end{array}$ & Proteobacteria & 99 & 502 & KM355745 \\
\hline W3 & $\begin{array}{l}\text { Pseudomonas } \\
\text { moraviensis }\end{array}$ & Proteobacteria & 99 & 507 & KF37660 \\
\hline W4 & Bacillus cereus & Firmicutes & 100 & 460 & KJ160221 \\
\hline W5 & Arthrobacter & Actinobacteria & 99 & 490 & JX860366 \\
\hline W6 & $\begin{array}{l}\text { Pseudomonas } \\
\text { koreensis }\end{array}$ & Proteobacteria & 99 & 488 & KM507148 \\
\hline W7 & Bacillus subtilis & Firmicutes & 99 & 507 & KF453784 \\
\hline
\end{tabular}




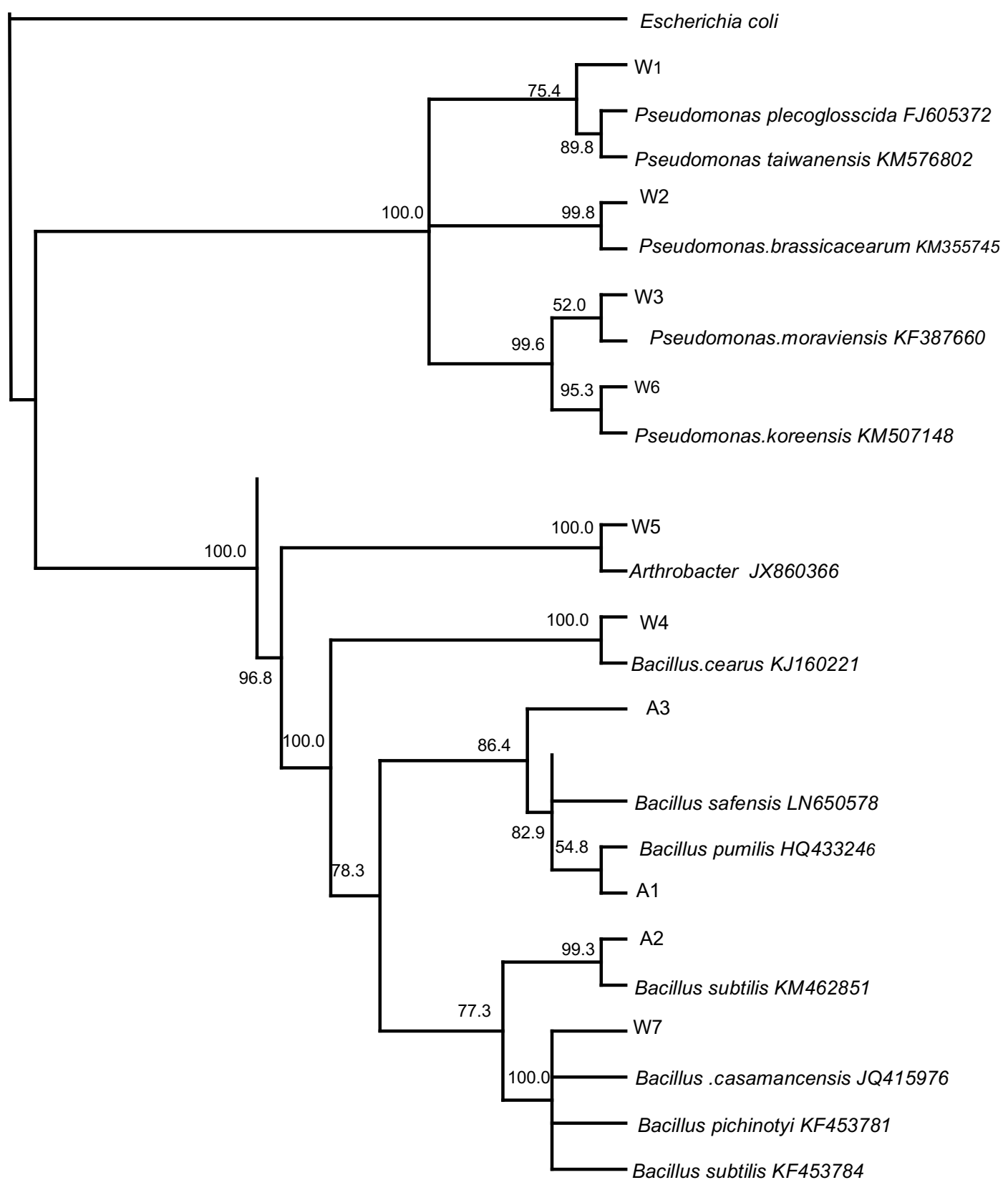

Fig. 2. Boot-strapped maximum-likelihood based phylogenetic tree indicating the evolutionary relationship between the isolated strains and the matching strains from the NCBI database. Boot-strap values of 50 or higher are given at the nodes; A1-A3: strains isolated from Abdally farms; W1-W7: Strains isolated from Wafra farms. 
3.2 Antibiotic susceptibility of the isolated bacterial strains

The antibiotic susceptibility of the isolated bacterial strains to 6 different antibiotics was examined, and the results are presented in Table 4. Based on the size of the zones, the susceptibility levels were defined as Resistant (R), Intermediate (I), and Susceptible (S). Most of the isolated strains were susceptible to Tetracycline except for strains W1 and W6. Some of the isolated bacterial strains showed susceptibility to more than one class of antibiotics. In addition to being susceptible to Tetracycline, the isolate A1 was susceptible to Co-trimoxazole and Streptomycin while A2 was susceptible to Co-trimoxazole, Nalidixic acid, and Chloramphenicol. A3 was susceptible to most of the antibiotics except for Streptomycin and Chloramphenicol. Strain W2 showed intermediate resistance to Nalidixic acid and Tetracycline. W4 was susceptible to Nalidixic acid and Chloramphenicol. While strains W1 and W6 were found to be resistant to all of the antibiotics tested. Strains W7 and W5 were shown to be resistant to all tested antibiotics except for Tetracycline. It should be noted that all strains were resistant to Ampicillin except the A3 isolate.

Table 4. Antibiotic susceptibility testing for bacteria isolated from tomato rhizosphere in Abdally (A1-A3) \& Wafra (W1-W7).

\begin{tabular}{|c|c|c|c|c|c|c|c|}
\hline \multirow[b]{2}{*}{ Lab designated sample ID } & \multirow[b]{2}{*}{ Bacteria strain identity } & \multicolumn{6}{|c|}{ Antibiotics $(\mu \mathrm{g})$} \\
\hline & & $\begin{array}{l}\text { Co } \\
25\end{array}$ & $\begin{array}{c}\text { NA } \\
30\end{array}$ & $\begin{array}{c}C \\
30\end{array}$ & $\begin{array}{c}\mathrm{S} \\
10\end{array}$ & $\begin{array}{c}\mathrm{T} \\
30\end{array}$ & $\underset{25}{\operatorname{Amp}}$ \\
\hline \multirow{3}{*}{ A1 } & Bacillus pumillis & & & & & & \\
\hline & & $\mathrm{S}$ & $\mathrm{R}$ & $\mathrm{R}$ & $\mathrm{S}$ & $\mathrm{S}$ & $\mathrm{R}$ \\
\hline & Bacillus subtilis KM462851 & & & & & & \\
\hline \multirow[t]{2}{*}{ A2 } & & $\mathrm{S}$ & $\mathrm{S}$ & $\mathrm{S}$ & $\mathrm{I}$ & $\mathrm{S}$ & $\mathrm{R}$ \\
\hline & Bacillus safensis & & & & & & \\
\hline \multirow[t]{2}{*}{ A3 } & & $\mathrm{S}$ & $\mathrm{S}$ & $\mathrm{R}$ & $\mathrm{R}$ & $\mathrm{S}$ & S \\
\hline & Pseudomonas plecoglosscida & & & & & & \\
\hline \multirow[t]{2}{*}{ W1 } & & $\mathrm{R}$ & $\mathrm{R}$ & $\mathrm{R}$ & $\mathrm{R}$ & $\mathrm{R}$ & $\mathrm{R}$ \\
\hline & Pseudomonas brassicacearum & & & & & & \\
\hline \multirow[t]{2}{*}{ W2 } & & $\mathrm{R}$ & I & $\mathrm{R}$ & $\mathrm{R}$ & I & $\mathrm{R}$ \\
\hline & Pseudomonas moraviensis & & & & & & \\
\hline \multirow[t]{2}{*}{ W3 } & & $\mathrm{R}$ & $\mathrm{R}$ & $\mathrm{R}$ & $\mathrm{R}$ & $\mathrm{S}$ & $\mathrm{R}$ \\
\hline & Bacillus cereus & & & & & & \\
\hline \multirow[t]{2}{*}{ W4 } & & $\mathrm{R}$ & $\mathrm{S}$ & $\mathrm{S}$ & $\mathrm{R}$ & $\mathrm{S}$ & $\mathrm{R}$ \\
\hline & Arthrobacter & & & & & & \\
\hline \multirow[t]{2}{*}{ W5 } & & $\mathrm{R}$ & $\mathrm{R}$ & $\mathrm{R}$ & $\mathrm{S}$ & $\mathrm{S}$ & $\mathrm{R}$ \\
\hline & Pseudomonas koreensis & & & & & & \\
\hline \multirow[t]{2}{*}{ W6 } & & $\mathrm{R}$ & $\mathrm{R}$ & $\mathrm{R}$ & $\mathrm{R}$ & $\mathrm{R}$ & $\mathrm{R}$ \\
\hline & Bacillus subtilis KF453784 & & & & & & \\
\hline W7 & & $\mathrm{R}$ & $\mathrm{R}$ & $\mathrm{R}$ & $\mathrm{R}$ & $\mathrm{S}$ & \\
\hline
\end{tabular}

$\mathrm{Co}=$ Co-Trimoxazole $\mathrm{C}=$ Chloramphenicol, NA=Nalidixic acid, Amp $=$ Ampicillin, $\mathrm{S}=$ Streptomycin, $\mathrm{T}=$ Tetracycline, $\mathrm{S}=$ sensitive, $\mathrm{R}=$ resistant, $\mathrm{I}=$ Intermediate. 


\subsection{Screening for potential PGPR activities}

Plant growth-promoting activities of the different bacterial isolates are shown in Table 5 and Figure 3. All bacterial isolates tested positive for Ammonia and Indole acetic acid (IAA) production. Strains A2 and $\mathrm{W} 1$ tested positive for all the tests, while strains A1 and W5 tested positive for every test except for Hydrogen cyanide (HCN) production. Strains A1, A2, W1, and W5, were the only ones that showed acid production and nitrogen-free media growth. Most of the strains displayed phosphate solubilizing ability except for W3, W6, and W7 (Table 5).

Table 5. Screening tests for potential PGPR activities.

\begin{tabular}{|c|c|c|c|c|c|c|c|c|c|c|}
\hline \multirow[t]{2}{*}{ Parameters } & \multicolumn{10}{|c|}{ Bacterial isolates as designated in the lab } \\
\hline & A1 & A2 & A3 & W1 & $\mathbf{W 2}$ & W3 & W4 & W5 & W6 & W7 \\
\hline $\begin{array}{l}\text { Ammonia } \\
\text { production }\end{array}$ & + & + & + & + & + & + & + & + & + & + \\
\hline $\mathrm{HCN}$ & - & + & - & + & - & + & - & - & - & - \\
\hline Acid production & + & + & - & + & - & - & - & + & - & - \\
\hline $\begin{array}{l}\text { Nitrogen-fixing } \\
\text { ability }\end{array}$ & + & + & - & + & - & - & - & + & - & - \\
\hline $\begin{array}{l}\text { Phosphate } \\
\text { solubilization }\end{array}$ & + & + & + & + & + & - & + & + & - & - \\
\hline IAA & + & + & + & + & + & + & + & + & + & + \\
\hline
\end{tabular}

IAA: Indole acetic acid; HCN: hydrogen cyanide; A1: Bacillus pumilis; A2: Bacillus subtilis KM462851; A3: Bacillus safensis; W1: Pseudomonas plecoglosscida; W2: Pseudomonas brassicacearum; W3: Pseudomonas moraviensis; W4: Bacillus cereus; W5: Arthrobacter; W6: Pseudomonas koreensis; W7: Bacillus subtilis KF453784.

Quantitative estimation of IAA produced by different bacterial isolates at different concentrations of tryptophan. The amount of IAA produced by each strain with and without the addition of tryptophan is presented in Table 6 and Figure 3. All the bacterial isolates were able to produce IAA with and without the addition of tryptophan supplement. The highest values were obtained for tryptophan values between 0.5 and 1 (Figure 3). 
Table 6. Estimation of IAA produced by the different isolates via a) tryptophan independent pathway and b) tryptophan dependent pathway as measured at $530 \mathrm{~nm}$.

\begin{tabular}{||lll||}
\hline Bacterial isolates $^{\mathbf{x}}$ & & \multicolumn{1}{c||}{ IAA produced $(\mu \mathrm{g} / \mathbf{m l})$} \\
& & \\
& No tryptophan & $0.5 \mathrm{mg}$ tryptophan \\
A1 & & \\
A2 & $22.7( \pm 0.02)^{\mathrm{y}} \mathrm{e}^{\mathrm{z}}$ & $103.5( \pm 0.03) \mathrm{c}$ \\
A3 & $14.3( \pm 0.02) \mathrm{f}$ & $107.4( \pm 0.03) \mathrm{b}$ \\
W1 & $30.7( \pm 0.04) \mathrm{d}$ & $111.6( \pm 0.02) \mathrm{a}$ \\
W2 & $36.4( \pm 0.01) \mathrm{b}$ & $105.93( \pm 0.01) \mathrm{c}$ \\
W3 & $34.19( \pm 0.08) \mathrm{c}$ & $110.6( \pm 0.03) \mathrm{a}$ \\
W4 & $30.6( \pm 0.03) \mathrm{d}$ & $103.87( \pm 0.07) \mathrm{c}$ \\
W5 & $30.6( \pm 0.01) \mathrm{d}$ & $107.07( \pm 0.02) \mathrm{b}$ \\
W6 & $23.6( \pm 0.05) \mathrm{e}$ & $101.17( \pm 0.05) \mathrm{c}$ \\
W7 & $65.9( \pm 0.03) \mathrm{a}$ & $104.92( \pm 0.03) \mathrm{c}$ \\
W7 & $34.3(+0.03) \mathrm{b}$ & $104.9(+0.3) \mathrm{c}$ \\
& $34.3( \pm 0.03) \mathrm{b}$ & $104.9( \pm 0.3) \mathrm{c}$ \\
\hline
\end{tabular}

x: Means are the average of three experiments ( $\mathrm{n}=10$ each). A1-3: strains isolated from Abdally; W1-7: strains isolated from Wafra. A1: Bacillus pumilis; A2: Bacillus subtilis KM462851; A3: Bacillus safensis; W1: Pseudomonas plecoglosscida; W2: Pseudomonas brassicacearum; W3: Pseudomonas moraviensis; W4: Bacillus cereus; W5: Arthrobacter; W6: Pseudomonas koreensis; W7: Bacillus subtilis KF453784.

y: Average values from different treatments rounded off to two decimal places \pm numbers in parenthesis $=$ standard deviation

z: Different letters next to the values indicate significant differences $(\mathrm{P}<0.05)$ between means. Means with the same letter are not significantly different at probability level $\mathrm{P}<0.05$ according to Duncan's multiple range test. 


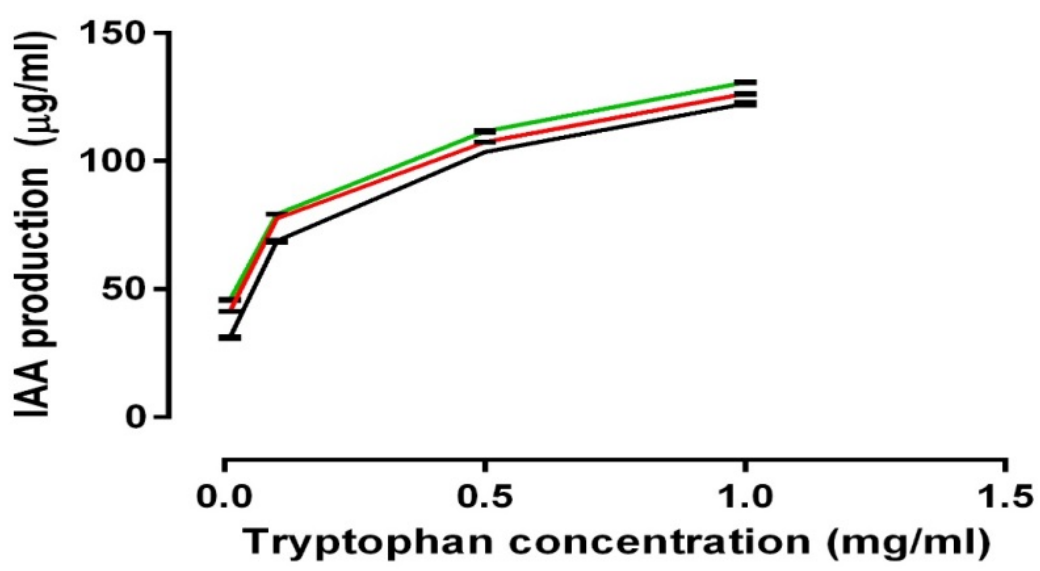

(A)

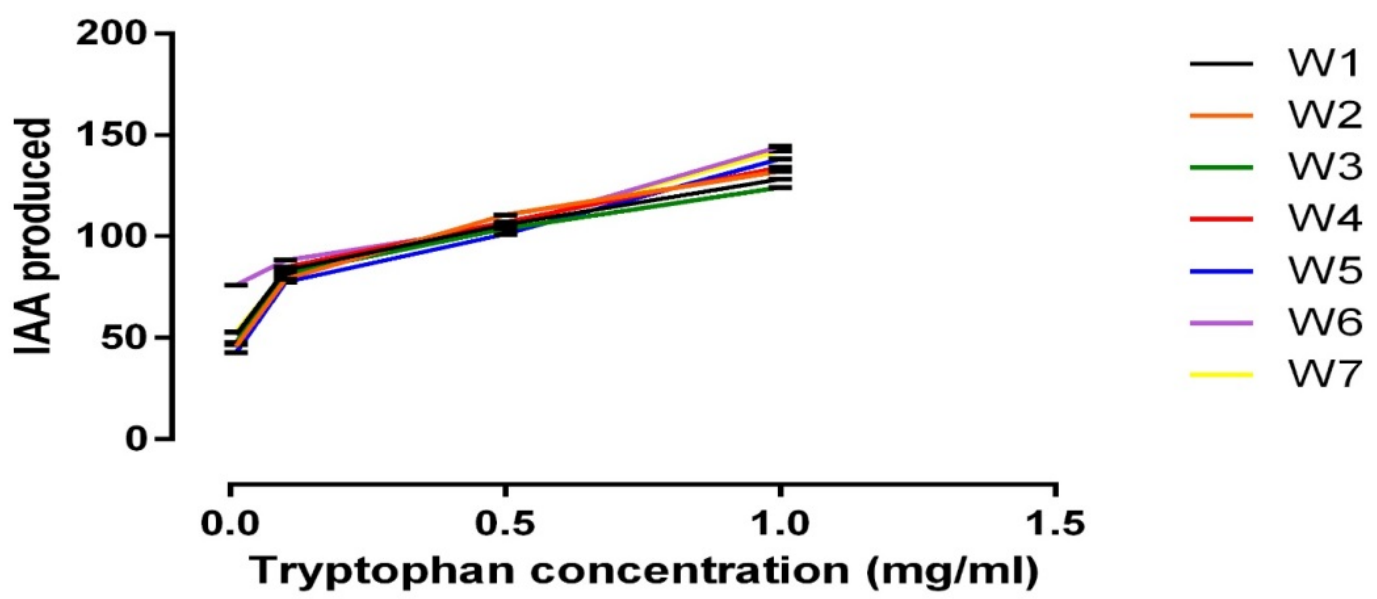

(B)

Fig. 3. Quantitative estimation of the amount of IAA produced by the different strains isolated from A) Abdally and B) Wafra with the variations in the concentration of the tryptophan supplement.

3.4 Greenhouse experiment to test the effect of the IAA producing bacterial isolates on the growth of tomato plants

Effects of the IAA producing bacterial isolates on the growth of tomato plants with and without the addition of tryptophan as a substrate are presented in Figure 4 and Tables $7 \& 8$. All bacterial isolates were able to promote the plants' height, weight, and leaf area compared to healthy. However, their individual effects varied from strain to strain (Figure 4). The isolates had variable effects on the plants' chlorophyll, protein, carbon, nitrogen, and proline content (Table 7). Most of the isolates had no significant effect on the carbon content, nitrogen, or the proline content of the plants (Table 7). The addition of tryptophan had a significant effect on the growth and the development of the tomato plants (Table 8). The results of the various tested growth parameters and the comparison between the effect of the bacterial isolates with and without the addition of tryptophan are presented in Figure 5 and Table 8 . No significant changes to the proline content or the nitrogen content of the plants (Table 8). 

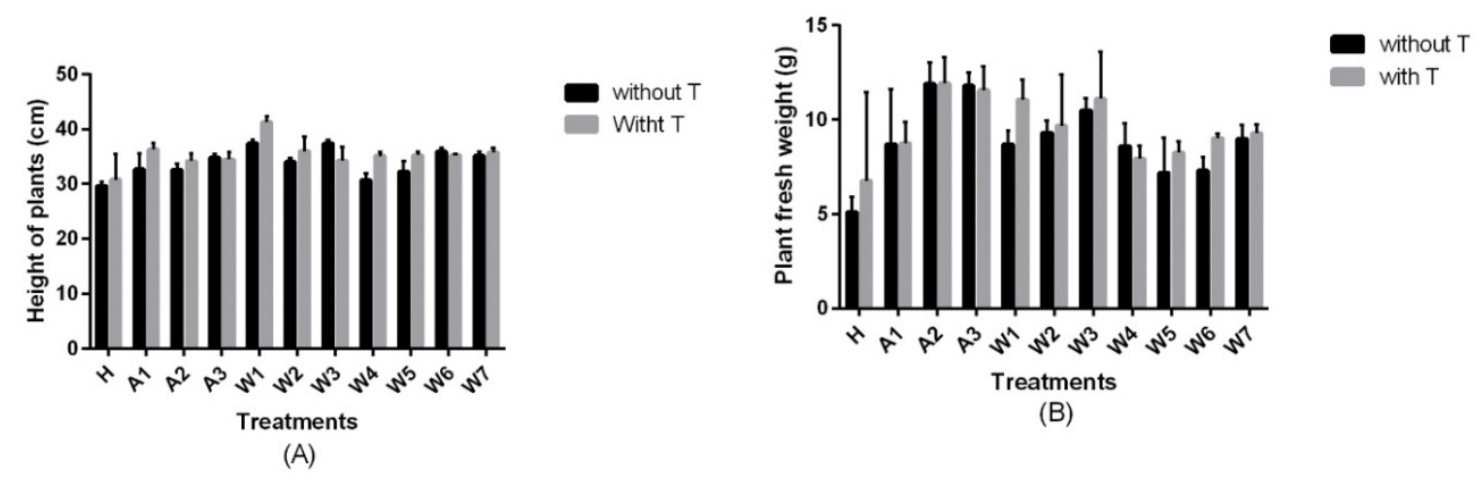

(B)

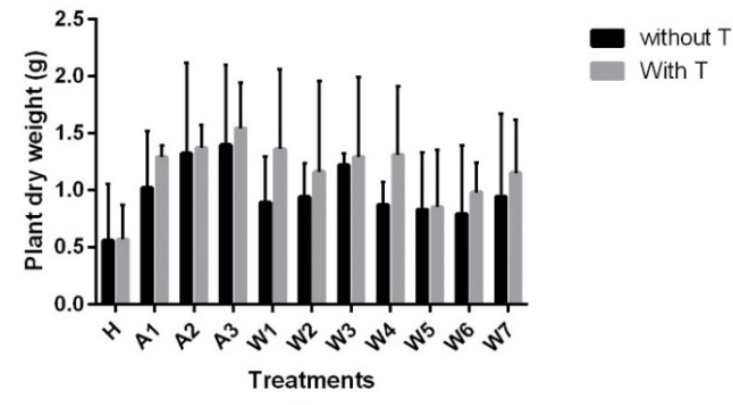

(C)

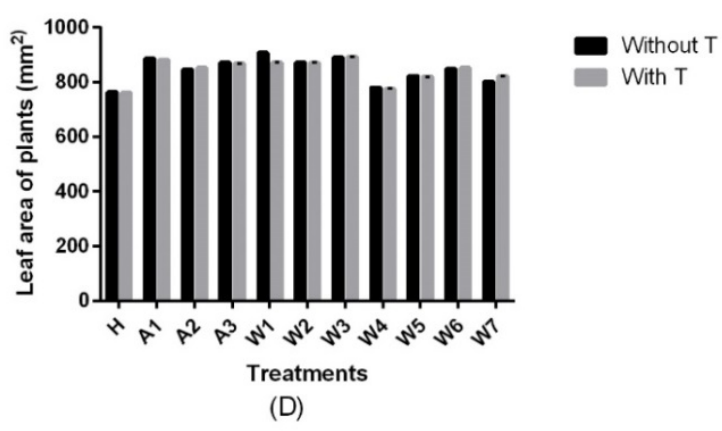

(D)

Fig. 4. Comparison of the effect of the different bacterial isolates on A) Height, B) Fresh weight, C) Dry weight, and D) Leaf area of the tomato plants with and without the addition of tryptophan to the soil. H: Healthy control; A1-3: Strains isolated from Abdally; W1-7: strains isolated from Wafra. The standard deviation values are indicated by error bars. 
Table 7. Effect of the different bacterial isolate on the chlorophyll, protein, carbon, nitrogen, and proline content of the plants with no tryptophan.

\begin{tabular}{|c|c|c|c|c|c|}
\hline $\begin{array}{l}\text { Sample } \\
\text { ID }^{x}\end{array}$ & $\begin{array}{l}\begin{array}{l}\text { Chlorophyll } \\
\text { content }\end{array} \\
(\mathrm{mg} / \mathbf{0 . 5 g})\end{array}$ & $\begin{array}{l}\begin{array}{l}\text { Protein } \\
\text { content } \\
(\mathrm{mg} / 0.2 \mathrm{~g})\end{array}\end{array}$ & $\begin{array}{l}\begin{array}{l}\text { Carbon } \\
\text { content }\end{array} \\
(\%)\end{array}$ & $\begin{array}{l}\begin{array}{l}\text { Nitrogen } \\
\text { content }\end{array} \\
(\%)\end{array}$ & $\begin{array}{l}\text { Proline } \\
\text { content }(\mu g / g)\end{array}$ \\
\hline $\mathbf{H}$ & $7.35( \pm 0.05)^{\mathrm{y}} \mathrm{d}^{\mathrm{z}}$ & $5.59( \pm 0.06) f$ & $32.68 \mathrm{c}$ & $6.92 b$ & $2.14( \pm 0.01) b$ \\
\hline A1 & $6.8( \pm 0.02) \mathrm{e}$ & $6.42( \pm 0.03) \mathrm{e}$ & $31.35 \mathrm{~d}$ & $6.82 b$ & $2.68( \pm 0.01) \mathrm{b}$ \\
\hline A2 & $10.35( \pm 0.02) \mathrm{a}$ & $7.36( \pm 0.03) \mathrm{d}$ & $32.16 \mathrm{c}$ & $7.36 \mathrm{a}$ & $2.87( \pm 0.01) \mathrm{b}$ \\
\hline $\mathbf{A 3}$ & $9.70( \pm 0.04) b$ & $9.20( \pm 0.02) b$ & $33.16 \mathrm{~b}$ & $6.46 \mathrm{~b}$ & $2.15( \pm 0.03) b$ \\
\hline W1 & $10.14( \pm 0.01) \mathrm{a}$ & $8.21( \pm 0.01) \mathrm{c}$ & $34.53 \mathrm{a}$ & $7.04 \mathrm{~b}$ & $2.04( \pm 0.01) b$ \\
\hline W2 & $7.81( \pm 0.08) \mathrm{d}$ & $8.84( \pm 0.03) \mathrm{c}$ & $31.13 \mathrm{~d}$ & $6.49 \mathrm{~b}$ & $4.66( \pm 0.04) \mathrm{a}$ \\
\hline $\mathbf{W 3}$ & $8.50( \pm 0.03) \mathrm{c}$ & $7.36( \pm 0.07) \mathrm{d}$ & $32.81 \mathrm{c}$ & $7.04 \mathrm{a}$ & $2.19( \pm 0.01) b$ \\
\hline W4 & $9.10( \pm 0.01) b$ & $\begin{array}{l}11.1(\mathrm{I} \quad \pm \\
0.02) \mathrm{a}\end{array}$ & $32.33 \mathrm{c}$ & $6.99 \mathrm{~b}$ & $2.39( \pm 0.04) b$ \\
\hline W5 & $7.96( \pm 0.05) \mathrm{d}$ & $5.92( \pm 0.05) \mathrm{f}$ & $32.36 \mathrm{c}$ & $7.03 \mathrm{a}$ & $2.96( \pm 0.04) \mathrm{b}$ \\
\hline W6 & $7.85( \pm 0.03) \mathrm{d}$ & $5.60( \pm 0.03) \mathrm{f}$ & $32.61 \mathrm{c}$ & $6.54 \mathrm{~b}$ & $2.33( \pm 0.02) \mathrm{b}$ \\
\hline W7 & $8.34( \pm 0.02) \mathrm{c}$ & $6.32( \pm 0.01) \mathrm{e}$ & $32.10 \mathrm{c}$ & $5.84 \mathrm{c}$ & $4.66( \pm 0.01) \mathrm{a}$ \\
\hline
\end{tabular}

x: Means are the average of three experiments ( $\mathrm{n}=10$ each). A1-3: strains isolated from Abdally; W1-7: strains isolated from Wafra. A1: Bacillus pumilis; A2: Bacillus subtilis KM462851; A3: Bacillus safensis; W1: Pseudomonas plecoglosscida; W2: Pseudomonas brassicacearum; W3: Pseudomonas moraviensis; W4: Bacillus cereus; W5: Arthrobacter; W6: Pseudomonas koreensis; W7: Bacillus subtilis KF453784.

y: Average values from different treatments rounded off to two decimal places \pm numbers in parenthesis $=$ standard deviation.

z: Different letters next to the values indicate significant differences $(\mathrm{P}<0.05)$ between means. Means with the same letter are not significantly different at probability level $\mathrm{P}<0.05$ according to Duncan's multiple range test. 
Table 8. Effect of the different bacterial isolates on the chlorophyll, protein, carbon, nitrogen, and proline content of the plants in the presence of tryptophan, the precursor for IAA production.

\begin{tabular}{||llllll||}
\hline $\begin{array}{l}\text { Sample } \\
\text { ID }\end{array}$ & $\begin{array}{l}\text { Chlorophyll } \\
\text { content }\end{array}$ & $\begin{array}{l}\text { Protein } \\
\text { content } \\
(\mathbf{m g} / \mathbf{0 . 2} \mathbf{g})\end{array}$ & $\begin{array}{l}\text { Carbon } \\
\text { content }\end{array}$ & $\begin{array}{l}\text { Nitrogen } \\
\text { content }\end{array}$ & $\begin{array}{l}\text { Proline } \\
\text { content } \\
(\boldsymbol{\mu M} / \mathbf{m l})\end{array}$ \\
H & $7.95( \pm 0.05)^{\mathrm{y}} \mathrm{d}^{\mathrm{z}}$ & $8.71( \pm 0.06) \mathrm{d}$ & $36.77 \mathrm{~d}$ & $5.86 \mathrm{~b}$ & $3.60( \pm 0.01) \mathrm{a}$ \\
A1 & $9.42( \pm 0.02) \mathrm{b}$ & $7.76( \pm 0.03) \mathrm{e}$ & $38.87 \mathrm{~b}$ & $6.12 \mathrm{a}$ & $2.60( \pm 0.01) \mathrm{b}$ \\
A2 & $10.17( \pm 0.02) \mathrm{a}$ & $8.57( \pm 0.03) \mathrm{d}$ & $37.10 \mathrm{c}$ & $5.84 \mathrm{~b}$ & $2.04( \pm 0.01) \mathrm{b}$ \\
A3 & $9.31( \pm 0.04) \mathrm{b}$ & $9.83( \pm 0.02) \mathrm{c}$ & $39.06 \mathrm{a}$ & $6.38 \mathrm{a}$ & $2.13( \pm 0.03) \mathrm{b}$ \\
$\mathbf{W 1}$ & $10.5( \pm 0.01) \mathrm{a}$ & $9.20( \pm 0.01) \mathrm{c}$ & $39.08 \mathrm{a}$ & $6.31 \mathrm{a}$ & $1.93( \pm 0.01) \mathrm{b}$ \\
$\mathbf{W 2}$ & $9.98( \pm 0.08) \mathrm{b}$ & $9.7( \pm 0.03) \mathrm{c}$ & $38.13 \mathrm{~b}$ & $6.28 \mathrm{a}$ & $2.62( \pm 0.04) \mathrm{b}$ \\
$\mathbf{W 3}$ & $9.33( \pm 0.03) \mathrm{c}$ & $10.4( \pm 0.07) \mathrm{b}$ & $37.59 \mathrm{c}$ & $5.98 \mathrm{~b}$ & $1.99( \pm 0.01) \mathrm{b}$ \\
$\mathbf{W} 4$ & $9.63( \pm 0.01) \mathrm{b}$ & $11.1( \pm 0.02) \mathrm{a}$ & $38.12 \mathrm{~b}$ & $5.91 \mathrm{~b}$ & $1.66( \pm 0.04) \mathrm{b}$ \\
$\mathbf{W 5}$ & $8.088( \pm 0.05) \mathrm{c}$ & $7.64( \pm 0.05) \mathrm{e}$ & $38.43 \mathrm{~b}$ & $5.98 \mathrm{~b}$ & $2.39( \pm 0.04) \mathrm{b}$ \\
$\mathbf{W 6}$ & $8.50( \pm 0.03) \mathrm{c}$ & $6.73( \pm 0.03) \mathrm{f}$ & $37.67 \mathrm{c}$ & $5.68 \mathrm{~b}$ & $2.98( \pm 0.02) \mathrm{b}$ \\
$\mathbf{W} 7$ & $9.34( \pm 0.02) \mathrm{b}$ & $6.55( \pm 0.01) \mathrm{f}$ & $37.00 \mathrm{c}$ & $5.58 \mathrm{~b}$ & $2.66( \pm 0.01) \mathrm{b}$ \\
\hline
\end{tabular}

x: Means are the average of three experiments ( $\mathrm{n}=10$ each). A1-3: strains isolated from Abdally; W1-7: strains isolated from Wafra. A1: Bacillus pumilis; A2: Bacillus subtilis KM462851; A3: Bacillus safensis; W1: Pseudomonas plecoglosscida; W2: Pseudomonas brassicacearum; W3: Pseudomonas moraviensis; W4: Bacillus cereus; W5: Arthrobacter; W6: Pseudomonas koreensis; W7: Bacillus subtilis KF453784.

y: Average values from different treatments rounded off to two decimal places \pm numbers in parenthesis $=$ standard deviation.

z: Different letters next to the values indicate significant differences $(\mathrm{P}<0.05)$ between means. Means with the same letter are not significantly different at probability level $\mathrm{P}<0.05$ according to Duncan's multiple range test. 


\section{Conclusion}

From the above study, it can be concluded that IAA plays a significant role in the growth and development of plants. This is especially significant because this paves way developing new and improved formulas for naturally improving the growth of plants. Ten strains were isolated from the rhizosphere of tomato in the Abdally and Wafra regions in Kuwait., five of them belonged to the Bacillus species, one was Arthrobacter, and 4 of them were Pseudomonas according to both biochemical and molecular characterization. All of the isolates were capable of producing IAA both in the presence and absence of tryptophan substrate. The conversion of tryptophan is one of the crucial steps in IAA production. As a result, there is generally an increased production of IAA when organisms are fed with tryptophan. Many bacteria such as Stryptomyces, Bacillus, and Pseudomonas show increased production of IAA in the presence of tryptophan. This study has isolated six different gram-positive PGPR strains that have shown excellent IAA producing capabilities.

Greenhouse experiments confirmed that IAA production is integral for plant growth. Most of the bacterial isolates were able to promote plant growth, shoot and root elongation, protein, and chlorophyll content.

Therefore, this research has laid the foundations for understanding how indigenous IAA producing bacteria in the tomato rhizosphere can improve the quality of the crop while re-inoculated back into the rhizosphere. This is clearly beneficial for improving the existing agricultural practices in the country and improves crop growth and fruit yield with no harm or consequences as we are using indigenous populations. This technology, if efficiently harnessed, can prove to be an economical and environmental friendly solution to sustainable agriculture.

\section{ACKNOWLEDGEMENTS}

This work has been supported by Kuwait University, Research Grant SL07/12.

\section{References}

Abbamondi, G.R.; Tommonaro, G.; Weyens, N.; Thijs, S.; Sillen, W. et al. (2016). Plant growth-promoting effects of rhizospheric and endophytic bacteria associated with different tomato cultivars and new tomato hybrids. Chemical and Biological Technologies in. Agriculture, 3:1.

Abraham, E.; Hourton-Cabassa, C.; Erdei, L. \& Szabados, L. (2010). Methods for determination of proline in plants. Methods in Molecular Biology, 639: 317331.

Al-Shatti, A. \& Al-Menaie, Habibah. (2015). Sustained Deficit Irrigation and Mulching on Growth of Sourani Olive Trees in Kuwait. World Journal of Engineering and Technology. 03. 52-56. 10.4236/wjet. 2015.33B009

Bashan, Y. \& De-Bashan, L.E. (2002). Protection of tomato seedlings against infection by Pseudomonas syringae pv. tomato by using the plant growthpromoting bacterium Azospirillum brasilense. Applied and Environmental Microbiology, 68(6): 2637-2643.

Caballero-Mellado, J.; Onofre-Lemus, J.; Estarada- De Los Santos, P. \& Martinez-Auguilar, L. (2007). The tomato rhizosphere, an environment rich in Burkholderia species with capabilities of interest for agriculture and bioremediation. Applied and Environmental Microbiology, 73(16): 5308-5319.

Dashti, N.; Khanafer, M.; El-Nemr, I.; Sorkhoh, N.; Ali, N. et al. (2009) The potential of oil-utilizing bacterial consortia associated with legume root nodules for cleaning oily soils. (2009) Chemosphere. 
74(10): 1354-1359.

doi:10.1016/j.chemosphere.2008.11.028.P

MID: 19103456.

Dashti, N.H.; Montasser, M.S.; Nedaa, Y.A.A. \& Cherian, V.M., (2014). Influence of plant growth-promoting rhizobacteria on fruit yield, pomological characteristics, and chemical contents in cucumber mosaic virus-infected tomato plants. Kuwait Journal of Science, 41(2): 205-220.

Gravel, V.; Antoun, H. \& Tweddell, R.J. (2007). Effect of Indole acetic acid (IAA) on the development of symptoms caused by Pythium ultimatum on tomato plants. European Journal of Plant Pathology, 119: 457-462.

Idris, E.E.; Iglesias, D.J.; Talon, M. \& Borriss, R. (2007). Tryptophan-dependent production of Indole 3- Actetic Acid (IAA) affects level of plant growth promotion by Bacillus amyloliquefacians FZB42. MPMI, 20(6): 619-626.

Jianfeng, W., Jinxiu, S., Haijie, D.\&Weifen, D. (2015). Non-destructive measurement of chlorophyll in tomato leaves using spectral transmittance. International Journal of Agriculture and Biological Engineering, 8(5): 73. http://pdfs.semanticscholar.org/685c/db3ce b8bb6f0ff1f768fa08171b82f6726cf.pdf.

Koskey, G.; Mburu, S. W.; Kimiti, J. M.; Ombori, O.; Maingi, J. M. et al. (2018). Genetic Characterization and Diversity of Rhizobium Isolated From Root Nodules of Mid-Altitude Climbing Bean (Phaseolus vulgaris L.) Varieties. Frontiers in microbiology, 9 , 968. https://doi.org/10.3389/fmicb.2018.00968

Kumar, D.P.; Anupama, P.D.; Singh, R.K.; Thenmozhi, R.; Nagasathya, A. et al. (2012). Performance studies of free living tomato (Lycopersicon esculentum L.) rhizospheric bacillus for their multiple plant growth-promoting activity. Journal of Soil
Science and Environmental Management, 3(6): 142-153.

Laslo, E.; Gyorgy, E.; Gyongyver, M.; Tamas, E.; Abraham, B., et al. (2012). Screening of plant growth-promoting bacteria as potential microbial inoculants. Crop Protection, 40: 43-48.

Mohite, B. (2013). Isolation and characterization of indole acetic acid (IAA) producing bacteria from rhizospheric soil and its effect on plant growth. Journal of Soil Science and Plant Nutrition, 13(3): 638-649.

Pavlopoulos, G. A.; Soldatos, T. G.; Barbosa-Silva, A., \& Schneider, R. (2010). A reference guide for tree analysis and visualization. BioData mining, 3(1):1. https://doi.org/10.1186/1756-0381-3-1.

Reetha, S.; Bhuvaneshwari, G.; Thamizhiniyan, P. \& Mycin, T.R. (2014). Isolation of indole acetic acid producing bacteria of Pseudomonas florescens and Bacillus subtilis and enhance the growth of onion (Allim cepa. L). International Journal of Current Microbiology and Applied Sciences, 3(2): 568-574.

Sahran, B. S. \& Nehra, V. (2011). Plant growth-promoting rhizobacteria: A critical review. Life Sci. Med. Research. 2011. Life Sciences and Medicine Research, 21: 1-30.

Shahid, S. A.; Omar, S. A. S; Jamal, M. E.; Shihab, A. \& Abo-Rizq, H. (2004). Soil survey for farm planning in Northern Kuwait. Kuwait Journal of Science and Engineering 31(1):43-57.

Sharma, T. \& Rai, N. (2015). Isolation of plant hormone (Indole-3 acetic acid) producing rhizobacteria and study on their effects on tomato (Lycopersicum esculentum) seedling. International Journal of PharmTech Research, 7(1): 99-107.

Wani, P. A \& Irene, I.O. (2014). Screening of Microbes for Their Metal Antibiotic Resistance and Plant Growth Promoting Activity. Current Research in Bacteriology, 7: 22-31. 
Isolation and characterization of novel plant growth-promoting rhizobacteria (PGPR) isolates from tomato (Solanum lycopersicum L.) rhizospherical soil: A novel IAA producing bacteria

Submitted : 29/09/2019

Revised $\quad: 14 / 05 / 2020$

Accepted $\quad: 18 / 06 / 2020$

DOI $\quad: 10.48129 /$ kjs.v48i2.8427 